\title{
Designing a Mobile Application for Autonomous Learning of English
}

\author{
S Rohani ${ }^{1}$, A Suyono ${ }^{2}$, I F Rozi ${ }^{3}$ \\ ${ }^{1,2,3}$ State Polytechnic of Malang \\ $\left\{{ }^{1}\right.$ siti.rohani@polinema.ac.id $\}$
}

\begin{abstract}
Despite its prominent role, university students encounter problems in progressing themselves in learning English. The situation gets worse when the allocated time of learning English in the classroom is not adequate. Several solutions can be proposed including the use of appropriate teaching and learning strategies as well as the implementation of autonomous learning. This study was aimed at developing a mobile phone application for autonomous learning of English. This study employed design and development research method, which was a product and tool research. Respondents were 166 students of State Polytechnic of Malang. Research methods used included questionnaires, interviews, and focus group discussions. Findings in the preliminary study showed that respondents needed additional time to learn English while mobile phones and computers were believed to be the most effective media. Findings from the field test revealed that the developed English mobile learning was considered interesting, motivating and useful to improve English.
\end{abstract}

Keywords: Autonomous Learning, Mobile Application, English Learning

\section{INTRODUCTION}

In addition to written communication skills, oral communication skills in English have become one of the main skills that must be mastered by students in Indonesia, and this has become the target of learning English in Indonesia. Studies show that some of the main objectives in learning English for students in Indonesia are oral communication in English, including 'talking with native speakers in work situations' and 'talking with native speakers in social situations' [1].

However, a lot of research reveal that the majority of Indonesian students are struggling in producing English spoken utterances. Despite this hindrance, skills in communicating in English are even considered as one of the most difficult skills to master. Most university graduates in Indonesia are unable to communicate verbally in English appropriately [2, 3].

Effective oral communication skills are vital for learners of English as a foreign language [4]. To support the effectiveness of oral communication 3 elements are needed, namely language, knowledge, and strategy supports [4]. For language support, learners need to be given adequate vocabulary mastery that can be given through reading or listening activities. With sufficient stock of lexicons, learners will more easily convey their intentions in their oral communication. Furthermore, knowledge support can be provided by providing sufficient knowledge about the topics to be discussed; this can also be done through reading or listening. 
The importance of mastering adequate vocabulary to support the smooth running of oral communication is also confirmed by Leaver, Ehrman, and Shekhtman [5]. It was stated that there were 2 things that inhibited the ineffectiveness of an oral communication: first, the learner did not have sufficient vocabulary mastery, and second, the learner did not know how to use the vocabulary in his spoken language. Meanwhile, the two barriers can be solved by giving many reading activities to learners [6-8].

The learning process will be effective by paying attention to the supporting factors such as learning methods or strategies. Learning materials that are interesting, challenging, and motivating for students, and the use of appropriate learning media. This is of course not separated from the use of technology.

Technology changes. Technology changes what we do and what we can do. People change on account of technology. Technology in support of learning and instruction is no different. Instructional technology changes what teachers and learners do and can do [9]. Therefore, the provision of learning materials must update to the latest technology.

The results of a review of the English system in all study programs at State Polytechnic of Malang (Polinema) conducted by Rohani et al [10] illustrate the lack of media use in the teaching and learning process in the classroom, especially those utilizing the advancement of technology. The learning materials provided are considered not really motivating students to further improve their English skills.

Next, the allocation of time for learning English in Polinema, especially for engineering students is considered insufficient. This was conveyed by both Polinema students and alumni. One of the solutions to this problem is providing media for independent or autonomous learning for Polinema students; independent learning that can be done outside the teaching and learning process in the classroom. Therefore, the development of learning materials in Polinema should consider the use of the latest technology that can be accessed by students outside of class hours and which can be accessed independently, of course with the supervision of lecturers.

Currently the use of advanced technology in learning English has been widely implemented, including the use of mobile phones. A lot of studies have been conducted to research or develop English language learning media using mobile phones [11-13]. Most of these applications are with reading, vocabulary, pronunciation content, which are not related to each other. However, the application content is not integrative. These applications are also very common, cannot be applied to help the process of learning English in Polinema. Therefore, it is necessary to do a design and development research, designing and developing a mobile learning application that supports independent English learning. This application should include materials to improve the four language skills, namely reading, listening, speaking, and writing skills as well as the two language components, namely pronunciation and intonation. All of these will lead to improved oral communication skills. All parts of this application should be made integrative, interesting, motivating, and adapted to the learning objectives.

This study was directed to respond the research problem of "how can a mobile learning application for autonomous learning of English be designed and developed to improve students' English skills?"

Learning foreign languages is a learning process to acquire four skills in foreign languages, namely reading, listening, speaking and writing skills, and the acquisition of four sets of language components, namely vocabulary, grammar, pronunciation, and cultural understanding [5]. Independent learning, also known as autonomous learning, began to be echoed since 1975 by Disick. Autonomous learning is interpreted as a learning approach that offers students free choices for four dimensions, namely goals, time, methods, and learning content [14]. The level 
of independence of learning varies, does not have to cover all dimensions, can also be adjusted to the conditions of students.

In line with Disick, Benson [15] defines autonomy as a capacity to take charge of, or take responsibility for, or control over your own learning. Autonomy also includes learners' abilities and attitudes that are adjusted to their level of autonomy. Likewise, Holec in Smith [16] highlights learner's autonomy as the learner's ability to control or regulate his own learning, which includes goals, material, syllabus, methods or techniques, time and place, and evaluation procedures. However, autonomous learning does not have to be total because it can be adapted to the conditions and needs of the learner.

Autonomous learning that allows to be applied in Polinema can include goals, material, time and place, to suit the needs of the students. Research by Rohani [8] proves the effectiveness of independent learning in extensive reading and individualized vocabulary learning in improving vocabulary skills, reading skills, and speaking skills. However, the application of autonomous learning is indeed need to be explored since there are obstacles, especially with the constraints of Indonesian culture [17], it is necessary to adjust the application of autonomous learning, which does not need total application. In this study, it is this adapted autonomous learning that was designed and developed, not total autonomous learning.

Mobile learning can be interpreted as learning using mobile media or learning by mobile learners [18]. More precisely, mobility must be understood not only as a displacement but also as a movement that can change time and across borders. Learner mobility will have an impact on the ever-changing learning environment:

...the mobile technology, while essential, is only one of the different types of technology and interaction employed. The learning experiences cross spatial, temporal and/or conceptual borders and involve interactions with fixed technologies as well as mobile devices. Weaving the interactions with mobile technology into the fabric of pedagogical interaction that develops around them becomes the focus of attention. [19]

The use of the latest technology as learning media, especially for independent learning, is absolutely essential. The use of this latest technology-based learning media has proven effective. There have been many studies in this field so that there is one particular field in language learning, known as Computer Assisted Language Learning (CALL). Some research examples in the field of CALL are those carried out by Chen \& Chung [20] and Golonka et al. [21].

The mobile learning media developed can use the latest programs such as automatic speech recognition (ASR) that can display pronunciation of one word or phrase and intonation of one sentence correctly and assess the results of the learner's voice recordings based on the criteria set in the application. The effectiveness of ASR has also been demonstrated in many studies [for example, 22]. Some development research is carried out by applying ASR to the application. Examples of these studies are those carried out by Bain \& Wald [22], Chiu \& Yeh [23], and Shadiev et al. [24]. The use of mobile phones in language learning also attracted the attention of many researchers. Thornton [13] and Cavus [12] are two examples of research in this field.

\subsection{Research Method}

This study was a design and development research, focusing on product and tool research [25]. There were four stages of the research followed as presented in Figure 2. Main respondents of the study were 166 students of State Polytechnic of Malang (Polinema) for the preliminary study. The try-out was done by involving students and lecturers to try out the application. Methods of data collection included questionnaire, interviews, and focus group discussion. 


\section{RESULT AND DISCUSSION}

\subsection{Preliminary Study}

Table 1. Students' Responses on the Questionnaire in the Preliminary Study

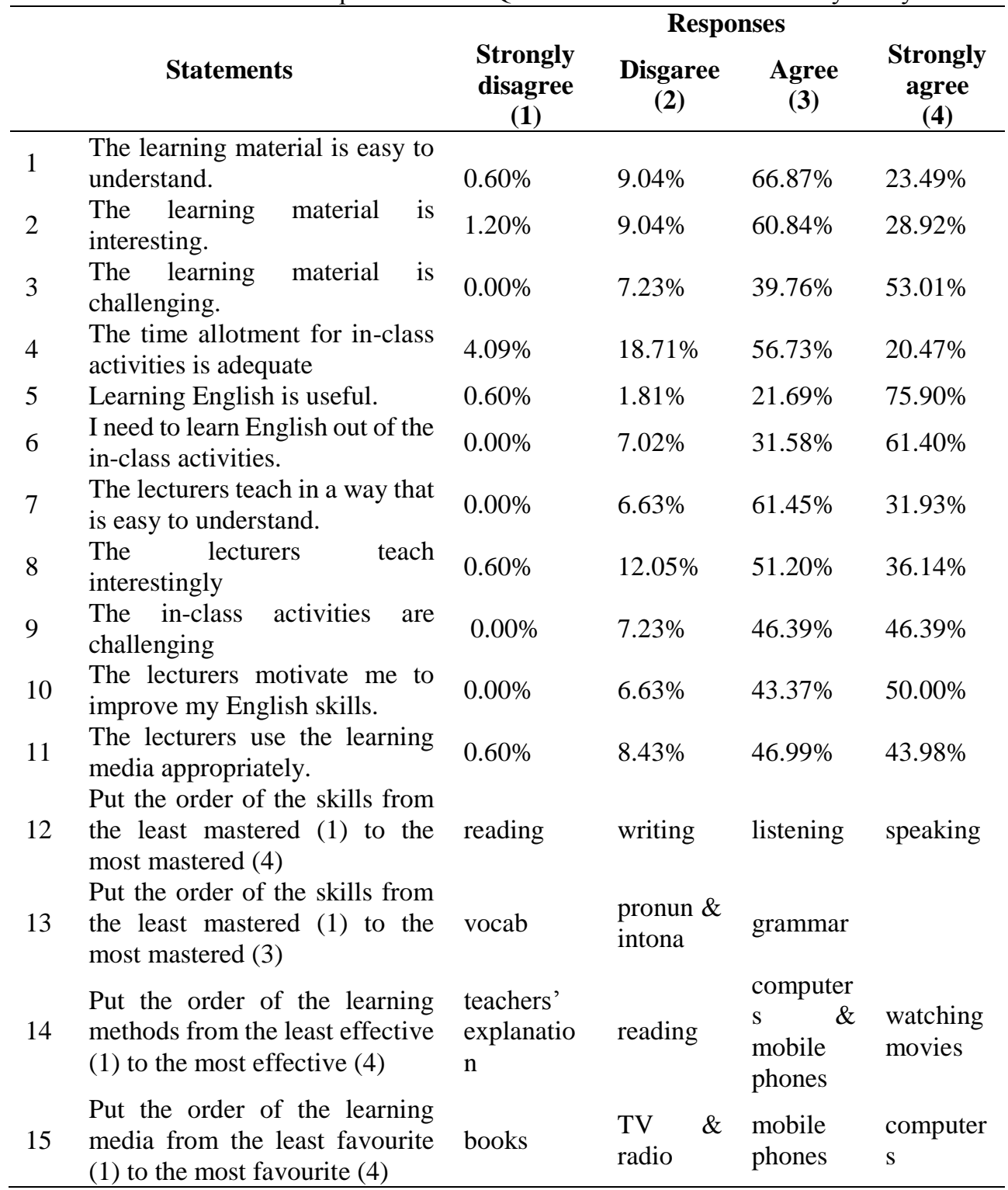

As seen in Table 1 above, most respondents believed that the teaching materials were easy to understand, interesting, challenging, and motivating. Responses regarding the lecturers, in general, also show positive voices. Lecturers taught interestingly. Majority of the respondents 
believed they needed more extra time to learn English; they needed to have autonomous learning of English. The use of media during the teaching and learning process was considered not really high.

Regarding the English language skills and components needed to be mastered, respondents reported that speaking was the most difficult to master. This was in accordance with the previous study by Bradford [1]. Furthermore, grammar was considered the most difficult components to master.

\subsection{The Development of Mobile Application}

The mobile application designed went through several times process and try-outs. The software used to develop the application included Adobe Photoshop CC, Android Studio version 3.1.4, Sublime Text Editor 3, and XAMPP. For use, the hardware should be a mobile smartphone with minimum RAM of $1 \mathrm{~GB}$ and 100MB free space. The mobile phone should be an android of version 4.1 Jelly Bean (API 16).

English@Polinema can be accessed by multiusers simultaneously from their Android devices (smartphones and tablets). The materials presented to the users were updated, corrected, and improved by a team of administrators consisting of application developers and subject matter experts in English learning material development.

What makes the application different from the application publicly published is that this application can be managed by the lecturers themselves. The learning materials that the users access in the application were adjusted to suit their needs and directed towards the attainment of specific learning outcomes. Therefore, when a certain learning outcome has been achieved, the contents of the application can be changed to suit to the new learning outcomes to be achieved. The use case of the application is presented in Figure 1.

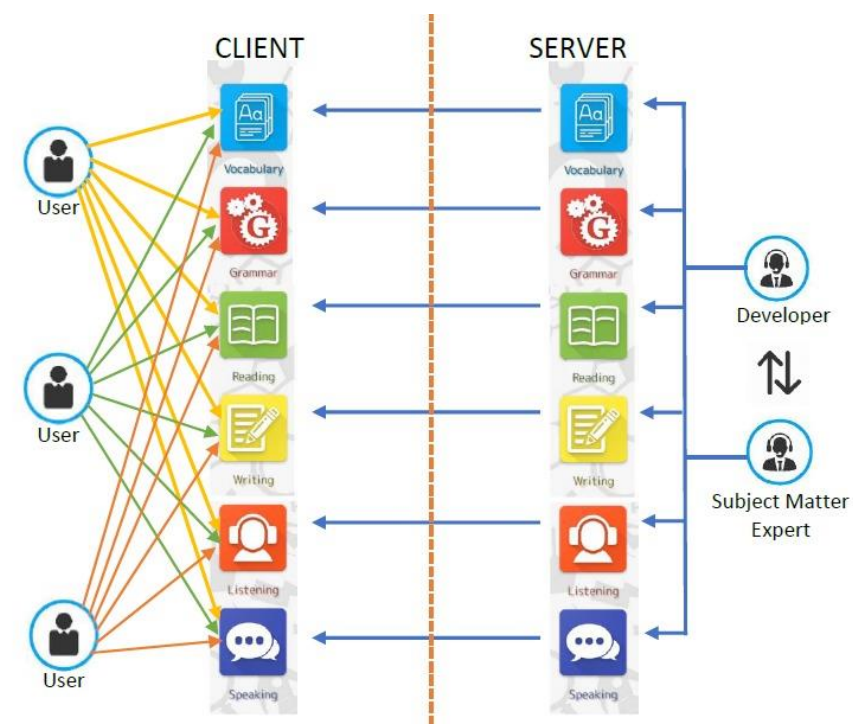

Figure 1. The Use Case of the Mobile Learning Application

There are four skills and two language components inputted as the content of the application. They included listening, reading, speaking, and writing skills as well as vocabulary and structure 
components. In the vocabulary section, for example, there are categories of vocabulary, equipped with pictures and the pronunciation. Users can also try to test his/her pronunciation and the application can determine the correctness of the pronunciation. Another example of description is in the speaking section which is divided into two parts, namely words and sentences. In each part, users can test the pronunciation and intonation of a certain word or sentence. The application will respond, determining the correctness of the pronunciation or intonation. Figure 2 shows the display of vocabulary and speaking sections.
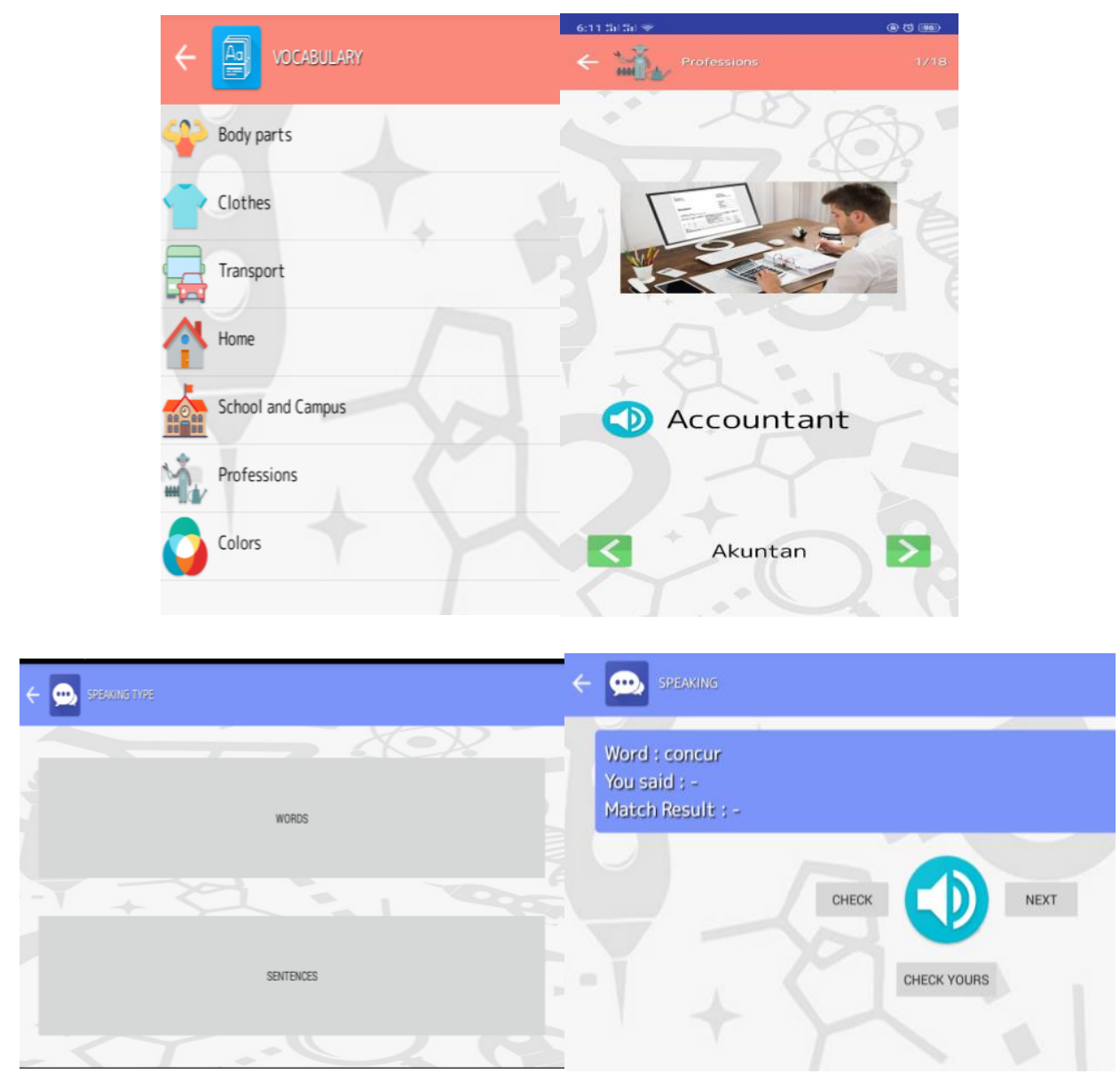

Figure 2. Displays of Vocabulary and Speaking Sections

After the application was developed, the phase was to try-out the application. Questionnaires were distributed to users, including students and lecturers. All respondents or application users were satisfied with an attractive, easy-to-understand interface, and the appropriate size and type of font. They also stated that application content was easy to understand and interesting. However, $18 \%$ of respondents stated that the application of the writing section was not useful while $9 \%$ of respondents stated that the application of speaking 
parts was less useful. In general, respondents stated that mobile learning applications were useful and interesting.

Respondents reported that watching movies was the most effective method to learn English. Making use of computers and mobile phones positioned the second, and listening to teachers' explanation in the classroom was the least effective one. These findings show respondents' preference to learn English in a more relaxed situation and more autonomously. This supports findings of previous studies, for example those conducted by Chen and Chung [20] or Golonka et.al. [21]. It is expected that the use of mobile learning can accommodate students' preference to learn autonomously, highlighting the effectiveness of autonomous learning as proven effective in previous studies (for example, Kweldju [7, 26] and Rohani [8]. Finally, findings that computers and mobile phones were selected as the most favored media of learning English support hundreds of previous studies on the successful use of computers and mobile phones in teaching and learning process (for example Bain \& Wald [22], Chiu \& Yeh [23], and Shadiev et al. [24]).

The combination of independent or autonomous learning by using computer learning media or mobile phone calls such as those designed in this study was responded positively by students. The survey results responding to mobile phone applications for self-learning are declared attractive, easy to understand, and useful for students (users). This supports previous studies such as the study by Cavus \& Ibrahim [12] which examined the use of SMS on mobile phones as a medium for learning vocabulary. Likewise, this study supports the study by Sandberg et al. [27] which proves a significant increase in English language skills of students who do learning outside the classroom by using mobile technology in addition to following classical learning in the classroom. Several other studies are in line, such as those conducted by Thornton \& Houser [13] which prove the effectiveness of mobile phone to improve students' English language skills in Japan. This is also in accordance with a research by Basoglu \& Akdemir [28] which prove that students' vocabulary improvement was significantly better when using mobile phone than using flash cards.

The results of this study also support Hsu [29] who examined the perception of mobile assisted language learning (MALL) users in learning English. Hsu's respondents from various countries in the world generally expressed the potential of MALL in constructivism in learning English. This is in line with the element of independence in learning the language that was carried out in this study.

What can be underlined in this study is that by facilitating student learning style preferences in learning English that tend to be relaxed, more independent, and use updated technology as learning media, it is expected that the English learning reveal effective. The output of this research which is mobile phone applications (android) for independent learning of English is one of the answers. By facilitating student learning style preferences, it is hoped that constructivism in learning English will also be fostered. In the end, in addition to increased English language skills, independent learning will foster the spirit of long-life learning.

\section{CONCLUSIONS}

This study reveals that autonomous learning of a foreign language can be done through using learning media favored by students. Learning English is a quite a long process of acquisition which cannot be done only through in-class activities, yet this should be accompanied by independent learning that can assist students to process the learning themselves. Teachers should facilitate this condition and should look at students' favored activities and media in order that the learning take place effectively. 


\section{REFERENCES}

[1] A. Bradford, "Motivational orientations in under-researched FLL contexts: Findings from Indonesia," RELC Journal, vol. 38, no. 3, pp. 302-323, December 1, 20072007.

[2] S. Dardjowidjojo, "English teaching in Indonesia," EA Journal, vol. 18, no. 1, pp. 22-30, 2000.

[3] C. Nur, "English language teaching in Indonesia: Changing policies and practical constraints," in English language teaching in East Asia today - Changing policies and practices, H. W. Kam and R. Y. L. Wong, Eds. second ed. Singapore: Eastern Universities Press, 2004.

[4] C. Goh, Teaching speaking in the language classroom (RELC portfolio series, no. 15). Singapore: SEAMEO Regional Language Centre, 2007, pp. ii, 48 p.

[5] B. L. Leaver, M. E. Ehrman, and B. Shekhtman, Achieving success in second language acquisition. Cambridge, UK ; New York: Cambridge University Press, 2005, pp. xiv, $265 \mathrm{p}$.

[6] J. Coady, "L2 vocabulary acquisition through extensive reading," in Second language vocabulary acquisition, J. Coady and T. Huckin, Eds. Cambridge: Cambridge University Press, 1997, pp. 225-237.

[7] S. Kweldju, English department students' vocabulary size and the development of a model of extensive reading with indiviudlaized vocabulary learning. Singapore: SEAMEO-Regional Language Centre, 1997.

[8] S. Rohani, "Maximizing a lexically-based extensive reading to improve students' reading and speaking skills," (Unpublished master's thesis), English Department, State University of Malang, Malang, 2005.

[9] M. Milrad, J. M. Spector, and P. Davidsen, "Building and Using Simulation Based Environments for Learning about Complex Domains," presented at the International Conference on Mathematics / Science Education and Technology 2000, 2000. Available: https://www.learntechlib.org/p/15460

[10] S. Rohani, H. Cahyani, and M. U. Hoesny, "Evaluasi Sistem Pembelajaran Bahasa Inggris di Polinema: Studi Komparasi antar Jurusan," Research Report, 2017.

[11] M. Ally and M. Samaka, "Open education resources and mobile technology to narrow the learning divide," 2013, vol. 14, no. 2, p. 14, 2013-06-03 2013.

[12] N. Cavus and D. Ibrahim, "m-Learning: An experiment in using SMS to support learning new English language words," British Journal of Educational Technology, vol. 40, no. 1, pp. 78-91, 2009.

[13] P. Thornton and C. Houser, "Using mobile phones in English education in Japan," Journal of Computer Assisted Learning, vol. 21, no. 3, pp. 217-228, 2005.

[14] R. S. Disick, Individualizing Language Instruction: Strategies \& Methods. New York: Harcourt Brace Jovanovich Inc., 1975.

[15] P. Benson, "Autonomy in language teaching and learning," Language Teaching, vol. 40, no. 01, pp. 21-40, 2007.

[16] R. Smith, "Learner autonomy," ELT Journal, vol. 62, no. 4, pp. 395-397, October 1, 2008 2008.

[17] S. Dardjowidjojo, "Cultural constraints in the implementation of learner autonomy: The case in Indonesia," Journal of Southeast Asian Education, vol. 2, no. 2, pp. 309-322, 2001.

[18] A. Kukulska-Hulme, "Will mobile learning change language learning?," ReCALL, vol. 21, no. 2, pp. 157-165, 2009. 
[19] A. Kukulska-Hulme, M. Sharples, M. Milrad, I. Arnedillo-Sa' nchez, and G. Vavoula, "Innovation in Mobile Learning: A European Perspective.," International Journal of Mobile and Blended Learning, vol. 1, no. 1, pp. 13-35, 2009.

[20] C.-M. Chen and C.-J. Chung, "Personalized mobile English vocabulary learning system based on item response theory and learning memory cycle," Computers \& Education, vol. 51, no. 2, pp. 624-645, 2008/09/01/ 2008.

[21] E. M. Golonka, A. R. Bowles, V. M. Frank, D. L. Richardson, and S. Freynik, "Technologies for foreign language learning: a review of technology types and their effectiveness," Computer Assisted Language Learning, vol. 27, no. 1, pp. 70-105, 2014/02/01 2014.

[22] K. Bain, S. H. Basson, and M. Wald, "Speech recognition in university classrooms: liberated learning project," presented at the Proceedings of the fifth international ACM conference on Assistive technologies, Edinburgh, Scotland, 2002.

[23] T.-L. Chiu, H.-C. Liou, and Y. Yeh, "A Study of web-based oral activities enhanced by Automatic Speech Recognition for EFL college learning," Computer Assisted Language Learning, vol. 20, no. 3, pp. 209-233, 2007/07/01 2007.

[24] R. Shadiev, W.-Y. Hwang, Y.-M. Huang, and C.-J. Liu, "Investigating applications of speech-to-text recognition technology for a face-to-face seminar to assist learning of non-native English-speaking participants," Technology, Pedagogy and Education, vol. 25, no. 1, pp. 119-134, 2016/01/01 2016.

[25] R. C. Richey and J. D. Klein, "Design and Development Research," New York: Routledge, Taylor \& Francis Group, 2009.

[26] S. Kweldju, "Sebuah model pengajaran mata kuliah membaca ekstensif dengan individualisasi pembelajaran kosa kata," Bahasa dan Seni, vol. 26, no. 1, 1998.

[27] J. Sandberg, M. Maris, and K. de Geus, "Mobile English learning: An evidence-based study with fifth graders," Computers \& Education, vol. 57, no. 1, pp. 1334-1347, 2011/08/01/ 2011.

[28] E. B. Basoglu and O. Akdemir, "A comparison of undergraduate students' English vocabulary learning: Using mobile phones and flash cards," Turkish Online Journal of Educational Technology - TOJET, vol. 9, no. 7, pp. 1-7, 2010.

[29] L. Hsu, "English as a foreign language learners' perception of mobile assisted language learning: a cross-national study," Computer Assisted Language Learning, vol. 26, no. 3, pp. 197-213, 2013/07/01 2013. 